\begin{tabular}{|c|l|}
\hline Title & Developmental regulation of photosynthate distribution in leaves of rice \\
\hline Author(s) & $\begin{array}{l}\text { SHINA NO, TA KURO; NA KA JIMA, KA NTO; WA SA KI, JUN; MORI, HA RUHIDE; ZHENG, TEI; OSA KI, } \\
\text { MITSURU }\end{array}$ \\
\hline Citation & $\begin{array}{l}\text { Photosynthetica, 44(1), 1-10 } \\
\text { https://doi.org/40.1007/311099-005-0151-6 }\end{array}$ \\
\hline Issue Date & 2006 \\
\hline Doc URL & http://hdl.handle.net/2115/946 \\
\hline Rights & The original publication is available at www.springerlink.com \\
\hline Type & article (author version) \\
\hline File Information & PH44 1.pdf \\
\hline
\end{tabular}

Instructions for use 


\title{
Developmental regulation of photosynthate distribution in leaves of rice
}

TAKURO SHINANO*, KANTO NAKAJIMA ${ }^{* *}$, JUN WASAKI", HARUHIDE MORI $^{* *}$, ZHENG TEI $^{* *}$, MITSURU OSAKI $^{* *}$

Creative Research Initiative "Sousei” (CRIS), Hokkaido University, Sapporo 0010021, Japan*

Graduate School of Agriculture, Hokkaido University, Sapporo 0608589, Japan**

Author for correspondence: Takuro Shinano. E-mail: takuro@chem.agr.hokudai.ac.jp

\begin{abstract}
mRNA expression patterns of genes for metabolic key-enzymes (sucrose phosphate synthase [SPS], phosphoenolpyruvate carboxylase [PEPC], pyruvate kinase, ribulose 1,5-bisphosphate carboxylase/oxygenase, glutamine synthetase 1 , and glutamine synthetase 2) were investigated in leaves of rice plants grown at two nitrogen $(\mathrm{N})$ concentrations. The relative gene expression patterns were similar in all leaves except for $9^{\text {th }}$ leaf, in which mRNA levels were generally depressed. Though an increased $\mathrm{N}$ concentrations prolonged the expression period of each mRNA, it did not affect the relative expression intensity of any mRNA in a given leaf. SPS $\mathrm{V}_{\max }$, SPS limiting activity, PEPC activity, and carbon flow were examined using ${ }^{14} \mathrm{CO}_{2}$. The ratio between PEPC activity and SPS $\mathrm{V}_{\max }$ was higher in leaves developed at the vegetative growth stage (vegetative leaves: $5^{\text {th }}$ and $7^{\text {th }}$
\end{abstract}


leaf) than in leaves developed after the ear primordia formation stage (reproductive leaves: $9^{\text {th }}$ and flag leaf). PEPC activity and SPS $\mathrm{V}_{\max }$ decreased with declining leaf $\mathrm{N}$ concentration. The ${ }^{14} \mathrm{C}$ photosynthate distribution to the amino acids fraction was higher in vegetative than in reproductive leaves when compared for the same leaf $\mathrm{N}$ status. Thus, at high PEPC activity to SPS activity ratio, more ${ }^{14} \mathrm{C}$ photosynthate was distributed to the amino acid pool, whereas at higher SPS activity, more ${ }^{14} \mathrm{C}$ was channeled into the carbohydrate fraction. Thus, leaf ontogeny was an important factor controlling photosynthate distribution to the Nor C-pool, respectively, regardless of leaf $\mathrm{N}$ status.

Additional key words: leaf development; mRNA expression; PEPC; photosynthate distribution; rice; SPS.

Abbreviatioins: C - carbon; DHAP - dihydroxyaceton phosphate; F6P - fructose 6-phosphate, G6P - glucose 6-phosphate; GS1 - glutamine synthetase 1; GS2 glutamine synthetase 2; MOPS - morpholinopropanesulphonic acid; N - nitrogen; PEP - phosphoenolpyruvate; PEPC - phosphoenolpyruvate carboxylase, PK pyruvate kinase; Rubisco - ribulose 1,5-bisphoshate carboxylase/oxygenase; SPS - sucrose phosphate synthase.

\section{Introduction}

It has been proposed that the distribution of photosynthetically fixed carbon (C) between amino acids and saccharides is regulated by the relative 
activities of sucrose phosphate synthase (SPS) and phosphoenolpyruvate carboxylase (PEPC; Champigny and Foyer 1992, Foyer et al. 1994, Huber et al. 1994). In $C_{3}$-plants, PEPC acts to replenish TCA cycle intermediates which serve as source material for the synthesis of amino acids (Stitt 1999). On the other hand, C distribution to sucrose increases with rising SPS levels (Worrel et al. 1991, Signora et al. 1998, Murchie et al. 1999). Galtier et al. (1993) demonstrated a positive relationship between SPS activity and the sucrose/starch ratio by changing the level of SPS in tomato transformed with a maize SPS gene, resulting in increased starch degradation in the chloroplasts. Similar effects were reported by Galtier et al. (1995) and Micallef et al. (1995). Thus, once dihydroxyacetone phosphate (DHAP) is released from the chloroplast, the rate of sucrose synthesis is regulated by SPS activity. On the other hand, DHAP released from chloroplasts can also be catabolized by pyruvate kinase (PK) or PEPC to fuel the synthesis of amino acids via the intermediates of the TCA cycle. When the $\mathrm{C}_{4}$-PEPC gene from Flaveria trinervia was introduced into potato plants, the C flow was redirected from sugar and starch synthesis to malate and amino acid synthesis (Rademacher et al. 2002). Vice versa, increased expression levels of SPS resulted in a decrease of amino acid synthesis (Laporte et al. 2001).

Previously we demonstrated that the ratio of SPS activity to PEPC activity in leaves of rice dramatically increased around the panicle primordia formation stage (Nakamura et al. 1997). The photosynthate distribution to amino acids was large at the vegetative growth stage, but decreased after the panicle primordia formation stage regardless of nitrogen (N) availability (Nakamura et al. 1997). 
One might expect that changes in C flow will also affect other enzymes, especially those involved in $\mathrm{C}$ and $\mathrm{N}$ metabolism in leaves.

In this study, we evaluated the interactive role(s) of C- and N-metabolism-related enzymes. We studied mRNA expression levels of SPS, PEPC, PK, ribulose 1,5-bisphosphate carboxylase/oxygenase (Rubisco), and glutamine synthetase (GS1, GS2), at different stages of leaf development. PK regulates C flow from DHAP to the TCA cycle, and Rubisco is the key enzyme for photosynthesis. Both GS1 and GS2 couple the ammonium ion to 2-keto glutarate. The cytosolic GS1 produces the substrate for further transamination reactions, and GS2 catalyzes the glycine to serine conversion in the chloroplasts (Buchanan-Wollaston and Ainsworth 1997). We determined mRNA expression patterns under low and high $\mathrm{N}$, because $\mathrm{N}$ application has been found to promote the expression of Rubisco (Plumley and Schmidt 1989), GS (Sakakibara et al. 1992), and PEPC (Suzuki et al. 1994).

In rice, amino acid (and protein) synthesis is more active during the vegetative growth stage, while carbohydrate synthesis is stimulated after the initiation of the reproductive stage. We did not detect a correlation of this physiological switch with expression patterns of C- and N-metabolism-related enzymes. Therefore, we determined changes of PEPC/SPS activity and the distribution of fixed ${ }^{14} \mathrm{C}$ to amino acids and the sucrose pool during rice plant development, in order to characterize the enzymatic basis of the physiological transition. 


\section{Materials and methods}

\section{Experiment 1}

\section{Plant material}

Rice plants (Oryza sativa L. cv. Michikogane) were sown on April 18 in a greenhouse and were transplanted in batches of six to 5 liter pots when they had reached the 5 leaf stage (June 12). To each pot, $2 \mathrm{~g} \mathrm{P}_{2} \mathrm{O}_{5}$ and $1 \mathrm{~g} \mathrm{~K}_{2} \mathrm{O}$ were applied as superphosphate and potassium sulfate, respectively. Ammonium sulfate was added at $0.5 \mathrm{~g} \mathrm{~N}(0.5 \mathrm{~N}$ treatment, standard concentration) or $3 \mathrm{~g} \mathrm{~N}(3.0 \mathrm{~N}$ treatment, excess concentration) per pot. All experiments were carried out with 4 replications.

\section{Sampling schedule}

For the analysis of mRNA expression, samples (upper two thirds of the leaf, not including the growth zone) were taken on May 31, June 19, June 28 (vegetative growth stage), July 8, July 19 (panicle formation stage), July 29, August 6 (flowering stage), August 17, August 26 (milk-ripe stage), September 4, September 11, September 20, and September 29. N concentration was determined for all samples, except for the small sized ones taken on May 31 and June 19. Samples from the vegetative, panicle formation, flowering, and milk-ripe stages were also used for analysis of enzyme activity and mineral content. Leaf samples were taken from the $3^{\text {rd }}, 5^{\text {th }}, 7^{\text {th }}, 9^{\text {th }}$, and flag leaf $\left(11^{\text {th }}\right.$ leaf $)$. For the determination of mRNA expression, samples were collected between 08:30 and 09:00 immediately frozen in liquid $\mathrm{N}$, and stored at $-80{ }^{\circ} \mathrm{C}$ until analysis. For the analysis 
of enzyme activity and mineral content, samples were taken between 09:00 and 10:00 am and weighed. Half of the samples were frozen in liquid $\mathrm{N}$ and stored at $-80{ }^{\circ} \mathrm{C}$ until analysis; the other half was dried at $80{ }^{\circ} \mathrm{C}$ for 48 hrs for mineral content analysis.

Mineral analysis

The $\mathrm{N}$ concentration was determined by the semi-micro Kjeldahl method.

RNA extraction and Northern analysis

Probes for PEPC and Rubisco were supplied by Dr. Makoto Matsuoka. Probes for PK, SPS, GS1, and GS2 were amplified using appropriate pairs of primers (5’-AAATTGTCCCCCAAAGATGGACTA and 5'-TCAGCTGTACAGAAGCAGTTGTGC for PK, 5'-ATCGACGGCGAGCGGGGG and 5'-GCAGGTAGTCCTGGTCGGGG for SPS, 5'-ACCGCCGACATCAACACC and 5'-TGGAAGCCCAGCAAGAAC for GS1, and 5'-GGGAGACTGGAATGGAG and 5'-TCGAGGGAAGGACGCAG for GS2) and rice cDNA as template.

Total RNA was isolated by the SDS/phenol method (Palmiter 1974). Ten $\mu \mathrm{g}$ of total RNA was denatured in 1 x MOPS, $\mathrm{pH} 7.0,16 \%$ (v/v) formaldehyde, and $50 \%$ formamide $(\mathrm{v} / \mathrm{v})$, and was separated on a $1 \%$ agarose gel that contained $1 \mathrm{x}$ MOPS, pH 7.0 and $5 \%$ formaldehyde (v/v). After electrophoresis, the purity of the RNA was checked by the expression of clear ribosomal RNA bands (data not shown), then RNA was transferred to a Hybond- $\mathrm{N}^{+}$membrane (Amersham 
Biosciences, Piscataway, NJ, USA), and fixed by UV radiation (CL-1000, UVP). The membranes were then hybridized in 5 x SSPE, pH 7.4, 5 x Denhardt's solution, $0.5 \%(\mathrm{~m} / \mathrm{v})$ SDS, and $20 \mu \mathrm{g} \mathrm{cm}{ }^{-3}$ denatured salmon-sperm DNA at $65^{\circ} \mathrm{C}$ for $18 \mathrm{~h}$ with probes that had been labeled with ${ }^{32} \mathrm{P}$ using the random-priming method (BcaBEST $^{\mathrm{TM}}$ Labeling Kit, Takara Bio, Shiga, Japan). The membranes were washed twice in 2 x SSPE, pH 7.4 and $0.1 \%$ (m /v) SDS at room temperature, and then in 1 x SSPE, pH 7.4 and $0.1 \%(\mathrm{~m} / \mathrm{v})$ SDS at $65{ }^{\circ} \mathrm{C}$ for $15 \mathrm{~min}$; finally they were rinsed with $0.1 \times$ SSPE and $0.1 \%(\mathrm{~m} / \mathrm{v})$ SDS.

After incubation with the SPS, PEPC, and PK probes, membranes were washed with boiling $0.5 \%(\mathrm{~m} / \mathrm{v})$ SDS, and rinsed with distilled water after cooling. These membranes then were used for reprobing with the GS1, GS2, and Rubisco probes. Membranes were exposed to an Imaging Plate (Fuji Bas-IIIs, Fuji film, Tokyo, Japan) for $30 \mathrm{~h}$ that was then examined with an image analysis system (Bas1000, Fuji Film,Japan).

Protein extraction and activity analysis

One g of sample was ground in liquid $\mathrm{N}$ and proteins were extracted at $4{ }^{\circ} \mathrm{C}$ by $6 \mathrm{~cm}^{3}$ of $50 \mathrm{mM}$ MOPS-NaOH, pH 7.5, $10 \mathrm{mM} \mathrm{MgCl}_{2}, 1 \mathrm{mM}$ EDTA, 2.5 mM DTT, $0.1 \%(v / v)$ Triton X-100, $10 \%$ (v/v) glycerine, $1 \%(\mathrm{~m} / \mathrm{v})$ PVP, and $0.1 \%$ (m /v) PMSF. The extract was centrifuged for $15 \mathrm{~min}$ at $13,500 \mathrm{~g}$ at $4{ }^{\circ} \mathrm{C}$. An aliquot of the supernatant was put on a $2.5 \mathrm{~cm}^{3}$ column, which had been prepared with $2.3 \mathrm{~cm}^{3}$ Sephadex G-25 (Amersham Biosciences) and equilibrated with the extraction buffer, excluding Triton X-100. 
PEPC activity was determined by the coupled reaction with malate dehydrogenase (Huber and Huber 1996). Twenty $\mathrm{mm}^{3}$ of the crude enzyme solution and $480 \mu \mathrm{l}$ of reaction buffer (50 mM MOPS-NaOH, pH 7.5, $15 \mathrm{mM}$ $\mathrm{NaHCO}_{3}, 5 \mathrm{mM}$ PEP, $15 \mathrm{mM} \mathrm{MgCl} 2,0.25 \mathrm{mM} \mathrm{NADH}$, and 12 units of malate dehydrogenase) were separately preheated at $30{ }^{\circ} \mathrm{C}$, mixed for $10 \mathrm{~s}$, and $5 \mathrm{~min}$ were allowed for the reaction. A reaction buffer without NADH was used as a blank. The decrease rate of NADH was determined using a spectrophotometer (UV-1600, Shimadzu, Tokyo). One unit of activity was defined as the amount of protein which turns over $1 \mu \mathrm{mol}$ of NADH in $1 \mathrm{~min}$.

In the case of SPS, both $\mathrm{V}_{\max }$ and limiting activity were determined (Quy et al. 1991). $\mathrm{V}_{\max }$ was measured under optimum conditions, while the limiting activity was measured at reduced concentration of activators (glucose-6-phosphate [G6P] and fructose-6-phosphate [F6P]) and in the presence of a deactivator (phosphate). Thirteen $\mathrm{mm}^{3}$ of crude enzyme solution were added to $40 \mathrm{~mm}^{3}$ of reaction buffer (for the measurement of $\mathrm{V}_{\max }: 50 \mathrm{mM}$ MOPS-NaOH pH 7.5, 15 $\mathrm{mM} \mathrm{MgCl} 2,10 \mathrm{mM}$ UDPG, $10 \mathrm{mM}$ F6P, $40 \mathrm{mM}$ G6P and $2.5 \mathrm{mM}$ DTT; for the determination of limiting activity: $50 \mathrm{mM}$ MOPS-NaOH pH 7.5, $15 \mathrm{mM} \mathrm{MgCl}_{2}$, 20 mM UDPG, 3 mM F6P, 12 mM G6P, 2.5 mM DTT and 10 mM phosphate). The reaction buffer and crude enzyme solution were separately preheated at $37{ }^{\circ} \mathrm{C}$, mixed, and the reaction was allowed to proceed for $15 \mathrm{~min}$. Seventy $\mathrm{mm}^{3}$ of $30 \%$ $(\mathrm{m} / \mathrm{v}) \mathrm{KOH}$ were added to stop the reaction, and the solution was heated $\left(100{ }^{\circ} \mathrm{C}\right.$ for $10 \mathrm{~min}$ ) to precipitate proteins. For a blank, $30 \% \mathrm{KOH}$ solution was added before the reaction. The released amount of sucrose phosphate was determined by 
adding $1 \mathrm{~cm}^{3}$ of $0.14 \%(\mathrm{~m} / \mathrm{v})$ anthron in $75 \% \mathrm{H}_{2} \mathrm{SO}_{4}$ and keeping the solution at $40^{\circ} \mathrm{C}$ for $20 \mathrm{~min}$, then storing it on ice until measurement of the absorbance at 620 nm (UV-1600, Shimadzu, Tokyo, Japan). One unit of activity was defined as the amount of protein which produces $1 \mu \mathrm{mol}$ of sucrose phosphate in $1 \mathrm{~min}$.

\section{Experiment 2}

Plant material

Rice seeds were sown on April 20 in a greenhouse and were transplanted to 5 liter pots in batches of four on June 1 . To each pot, $1 \mathrm{~g} \mathrm{~N}, 2 \mathrm{~g} \mathrm{P}_{2} \mathrm{O}_{5}$, and $1 \mathrm{~g}$ $\mathrm{K}_{2} \mathrm{O}$ were added as ammonium sulfate, superphosphate, and potassium sulfate, respectively. All experiments were carried out with 4 replications. Samples were taken on June 29 (vegetative growth stage), July 11 (panicle formation stage), July 20 (flowering stage), and August 11 (milk-ripe stage).

${ }^{14} \mathrm{CO}_{2}$ assimilation and ${ }^{14} \mathrm{C}$ analysis

Each leaf was covered with clear polyethylene bags filled with natural air. ${ }^{14} \mathrm{CO}_{2}$ was liberated underneath the bag by mixing $5 \mathrm{~cm}^{3}$ of $0.18 \mathrm{mM} \mathrm{NaHCO}$ with $1.85 \mathrm{MBq} \mathrm{NaH}{ }^{14} \mathrm{CO}_{3}$ and $5 \mathrm{~cm}^{3}$ of $300 \mathrm{mg} \mathrm{dm}^{-3} \mathrm{HClO}_{4}$, and the plants were allowed to assimilate for 5 min under natural light conditions (between 800 and $1200 \mu \mathrm{mol} \mathrm{m}^{-2} \mathrm{~s}^{-1}$ ). The $\mathrm{CO}_{2}$ concentration after this period was not lower than 200 $\mu \mathrm{mol} \mathrm{mol}{ }^{-1}$ in any of the experiments. All leaves were collected between 0 and 30 min after exposure to ${ }^{14} \mathrm{CO}_{2}$, and were frozen in liquid $\mathrm{N}$ for storage.

Total ${ }^{14} \mathrm{C}$ was measured as described by Shinano et al. (1996), and the 
distribution of ${ }^{14} \mathrm{C}$ among various classes of chemical compounds (sugars, free amino acids, organic acids including sugar phosphates, protein amino acids, polysaccharides) was determined as detailed by Shinano et al. (1994).

\section{Mineral analysis and enzyme activity}

Mineral analysis and enzyme activity were determined as described for Experiment 1.

\section{Results}

Experiment 1

Leaf $N$ content

The $\mathrm{N}$ content of all leaves declined over time, but the rate of decrease was higher in the $0.5 \mathrm{~N}$ than in the $3.0 \mathrm{~N}$ treatment (Fig. 1).

\section{Expression of individual mRNAs}

Using same amount of total RNA as a reference, relative amounts of specific mRNAs were compared in leaves of any given position (Fig. 2). As the content of total RNA from the last samplings was too small for further analysis (data not shown), the values for individual mRNAs were assumed to be 0 at these dates (Fig. 2). This occurred earlier in the $0.5 \mathrm{~N}$ treatment, since leaf senescence commenced earlier in the $0.5 \mathrm{~N}$ than in the $3.0 \mathrm{~N}$ treatment.

SPS: In all leaves, relative SPS mRNA levels increased with time, and decreased after full expansion of the leaf (Fig. 2). At 34 days after transplanting 
(DAT), the relative levels were higher in the $5^{\text {th }}$ than in the $7^{\text {th }}$ and $9^{\text {th }}$ leaf.

PEPC: The relative amounts of PEPC mRNA reached a maximum just before senescence. Levels were higher in the $3^{\text {rd }}$ and $5^{\text {th }}$ leaf than in the $7^{\text {th }}$ and $9^{\text {th }}$ one.

PK: The expression pattern was similar to that of PEPC. Relative expression levels were similar in all but the $9^{\text {th }}$ leaf.

Rubisco: The relative expression level of Rubisco mRNA generally declined gradually over the experimental period.

GS1: The expression level of GS1 was low initially, but then increased. This was especially evident in the $5^{\text {th }}, 7^{\text {th }}$, and flag leaf (Fig. 2).

GS2: The pattern of GS2 expression was similar to that of SPS (Fig. 2), but its peak occurred one week earlier.

\section{SPS and PEPC activity}

In plants of the $0.5 \mathrm{~N}$ treatment, PEPC activity decreased with time, but it was rather constant in the $3.0 \mathrm{~N}$ treatment (Fig. 3). The maximum PEPC activity measured in leaves of any given position tended to be higher in leaves that developed earlier (leaf 5 and 7) than in younger ones (leaf 9 and flag leaf).

In the $0.5 \mathrm{~N}$ treatment, SPS $\mathrm{V}_{\max }$ decreased over the period of observation in all leaves (Fig. 3). The decline in SPS limiting activity (which represents the actual activity in the tissue) was less pronounced. In the $3.0 \mathrm{~N}$ treatment, a decrease in $\mathrm{V}_{\max }$ was observed in all leaves except for leaf 9, although the decreasing rate was small and activity was maintained at a high level even at the last sampling date. 
No clear tendency became evident in the time-course of SPS limiting activity in this treatment.

The activities of SPS and PEPC were positively correlated in leaves that developed during the vegetative stage (vegetative leaves: $5^{\text {th }}$ and $7^{\text {th }}$ leaf) as well as in leaves developed during the reproductive stage (reproductive leaves: $9^{\text {th }}$ and flag leaf; Fig. 4. Results from both $\mathrm{N}$ treatments were pooled for this figure.). The ratio of PEPC activity to SPS $V_{\max }$ or SPS limiting activity, respectively, was generally higher in vegetative than in reproductive leaves (Fig. 4). There were positive correlation between $\mathrm{N}$ content and each of the enzyme activities tested in vegetative and reproductive leaves, except for SPS limiting activity in vegetative leaves (Fig. 5).

\section{Experiment 2}

Distribution of ${ }^{14} \mathrm{C}$

Before the panicle primordia formation stage (approximately 45 days after transplanting), the fraction of assimilated ${ }^{14} \mathrm{C}$ incorporated into free amino acids and protein amino acids (designated as the $\mathrm{N}$-pool) at the end of the $5 \mathrm{~min}$ period of ${ }^{14} \mathrm{C}$ assimilation was higher than in later stages in all leaves examined (Fig. 6). The relative ${ }^{14} \mathrm{C}$ content of sugars and polysaccharides (the $\mathrm{C}$-pool) increased accordingly.

Though the correlation between $\mathrm{N}$ content and ${ }^{14} \mathrm{C}$ distribution ratio to the $\mathrm{N}$ pool was positive both in vegetative leaves (only leaf 6 was examined) and reproductive leaves (leaves $8,9,10$, and 11 ), the distribution ratio to $\mathrm{N}$ pool was 
higher in the vegetative leaf at any given value of nitrogen content (Fig. 7).

\section{Discussion}

To study changes of relative expression levels of mRNA during development, we selected 6 genes related to the acquisition of $C$ (Rubisco), the distribution of $\mathrm{C}$ to sucrose (SPS), the distribution of $\mathrm{C}$ to the TCA cycle (PEPC, $\mathrm{PK}$ ), the distribution of $\mathrm{C}$ to the photorespiratory $\mathrm{N}$ cycle (GS2), and $\mathrm{N}$ translocation (GS1). The highest relative expression was observed in Rubisco followed by GS2, SPS and PK, PEPC, and GS1. SPS facilitates C removal from chloroplasts, helping to maintain a high photosynthetic rate. PK is crucial for glycolytic C flux to pyruvate (Copeland and Turner 1987, Plaxton et al. 1993, Plaxton 1996). The relative expression levels of each mRNA were similar in leaves of different ages, except for the PEPC mRNA, which accumulated more strongly in leaves at late growth stages. Since ammonium and glutamine activate PEPC mRNA expression (Sugiharto et al. 1992), nitrogenous compounds derived from protein degradation during leaf senescence must be expected to stimulate PEPC mRNA expression.

GS1 is localized in the cytosol while GS2 acts in chloroplasts. Both enzymes catalyze the ATP-dependent condensation of $\mathrm{NH}_{3}$ with glutamate to produce glutamine. The time-courses of relative mRNA levels of these enzymes differed in the rice leaves we studied (Fig. 2). GS1 protein concentration increase during leaf senescence, while the concentration of GS2 decline in parallel with the decrease of chlorophyll, Rubisco, and soluble proteins (Kawakami and Watanabe 
1988, Kamachi et al. 1991). These patterns illustrate the roles of GS1 in the synthesis of translocatable nitrogenous compounds (glutamine) in the senescent leaf, and of GS2 in capturing ammonium molecules which are released during photorespiration (Kozaki and Takeba 1996). Though mRNA levels do not necessarily correspond to the levels of the corresponding proteins, the similarity of the time-courses of relative mRNA levels of Rubisco and GS2 indicates the involvement of GS2 in photosynthesis-related processes (Fig. 2).

In contrast to the later developing leaves, patterns of relative mRNA levels did not respond to $\mathrm{N}$ application in leaf 3 (Fig. 2). Apparently, the temporal patterns of gene expression in leaf 3 are already determined during early leaf development in the seed, before the seedling comes into contact with exogenous $\mathrm{N}$ sources. In younger leaves, mRNAs were accumulated at higher absolute levels and over a longer period in the high $\mathrm{N}$ treatment. However, mRNA concentrations expressed as relative levels were similar in the $0.5 \mathrm{~N}$ and $3.0 \mathrm{~N}$ treatments.

In the $9^{\text {th }}$ leaf, relative mRNA levels tended to be lower than in other leaves, regardless of the $\mathrm{N}$ treatment (Fig. 1). This might be related to the switch from the vegetative to the reproductive stage. In contrast to the older leaves, the primordium of leaf 9 is not formed at the early vegetative growth stage, but at the ear primordia formation stage. During the vegetative stage, $\mathrm{N}$ metabolism is highly active to support the generation of new organs, while at the reproductive stage $\mathrm{C}$ metabolism takes over to enable the accumulation of starch in the developing seeds. Therefore, we expected the expression patterns of genes related to $\mathrm{C}$ and $\mathrm{N}$ metabolism, respectively, to change in opposite senses in the $9^{\text {th }}$ leaf. This was not 
the case; rather, mRNA levels were depressed generally. Similarly, we expected PEPC mRNA to accumulate to higher levels at the vegetative growth stage, and SPS mRNA to increase at the reproductive stage. However, our expectation was not met.

In whole rice plants, the $\mathrm{C} / \mathrm{N}$ ratio increases exponentially with growth (Osaki et al. 1992). Our results indicated that initial photosynthate distribution (within 5 min of carbon fixation) to the $\mathrm{N}$-pool was high before the panicle primordia formation stage, but decreased thereafter (Fig. 6). Moreover, the balance of PEPC and SPS activities changed around the panicle primordia formation stage (Fig. 4, Nakamura et al. 1997). These findings were in accord with the proposal that the alternative allocation of DHAP-derived $\mathrm{C}$ to the synthesis of amino acids or sucrose is regulated by the relative strengths of PEPC and SPS (Champigny and Foyer 1992).

As shown in Fig. 4, the ratio of the activities of PEPC and SPS was higher in the $5^{\text {th }}$ and $7^{\text {th }}$ leaf (which developed during the vegetative growth stage) than in the $9^{\text {th }}$ and flag leaf (whose primordia were formed after panicle primordia formation and which grow during the reproductive growth stage). The relationship between $\mathrm{N}$ concentration and SPS $\mathrm{V}_{\max }$ as well as PEPC activity was significantly different between leaves growing in the vegetative or the reproductive stage (Fig. 5). Thus, not only leaf position (growth stage) but also the $\mathrm{N}$ content of the leaf regulates the activity of both enzymes. Moreover, $\mathrm{N}$ concentration and PEPC were strongly correlated (Fig. 5c), indicating that the relative activity of PEPC decreases as leaf $\mathrm{N}$ declines during leaf development. 
Our results (Fig. 5c) are in agreement with the fact that levels of PEPC increased with $\mathrm{N}$ concentration in $\mathrm{C}_{3}$ plants including wheat, barley, tomato (Koga and Ikeda 1997), ryegrass (Sagi et al. 1998), and Norway spruce (Wallenda et al. 1996). Moreover, PEPC activity is positively correlated with the $\mathrm{N}$ assimilation rate (Vanlerberghe et al. 1990). This makes sense as PEPC supplies C to the TCA cycle from which the synthesis of amino acids starts. SPS is considered to be a key enzyme to regulate glucose synthesis (Stitt et al. 1987, Huber and Huber 1992). It is reported that both SPS and PEPC activity is tightly regulated by metabolites (such as glucose 6-phosphate and phosphate in the case of SPS (Stitt et al. 1988), and malate, aspartic acid, and glutamic acid in the case of PEPC (Huppe and Turpin 1994)), as well as by reversible phosphorylation by PEPC kinase and protein phosphatase (Vidal and Chollet 1997). Activity of cytoplasmic SPS and PEPC is known to be regulated by phosphorylation and dephosphorylation (Foyer et al. 1995, MacKintosh 1998). While photosynthesis provide precursors as a signal to promote the activation (dephosphorylation) of SPS and activation (phosphorylation) of PEPC in the cytosol. But high nitrate application promotes the activation of PEPC but not SPS (Foyer et al. 1995). Feeding maize with ammnoinium or nitrate increased PEPC protein level and mRNA via cytokinin-dependent transcription of the PEPC gene (Sugiharto and Sugiyama 1992, Suzuki et al. 1994). The regulation of PEPC protein by nitrogen nutrition is known by phosphorylation when nitrate was fed to nitrogen deficient wheat leaf (Duff and Chollet 1995). These are recognized as overall effect would tend to activate sucrose synthesis by SPS and amino acids synthesis by PEPC. Thus the 
observed difference in the expression pattern of mRNA of SPS and PEPC were different from that of the enzymatic activity pattern, suggesting to be regulated by the biochemical function on enzyme.

The ratio of the SPS limiting activity and the PEPC activity is thought to represent the relative intensity of $\mathrm{C}$ flow from DHAP to either sucrose or amino acids. In individual leaves, the ${ }^{14} \mathrm{C}$ distribution to the $\mathrm{N}$-pool decreased with time, especially after the panicle primordia formation stage (Fig. 6). The ${ }^{14} \mathrm{C}$ distribution to the N-pool and C-pool is regulated primarily by the $\mathrm{N}$ status in leaves and leaf ontogeny as shown in Fig. 8. We conclude that the photosynthates are distributed to the C-pool and the $\mathrm{N}$-pool before translocation from the leaves. However, ${ }^{14} \mathrm{C}$ distribution to the N-pool was not always strictly depending on $\mathrm{N}$ concentration, but was also influenced by leaf position, that is, the leaf developmental stage (Fig. 7). The regulation by PEPC of $\mathrm{C} / \mathrm{N}$ partitioning in nodules is also reported (Taybi et al. 2000, Bakrim et al. 2001), but the role of PEPC and SPS on the regulation of $\mathrm{C} / \mathrm{N}$ partitioning along with the development of a leaf is not known.

Along with leaf development, as soon as the leaf reaches a specific stage of development, the sink to source transfer occurs in the leaf (Fellows and Geiger 1974, Turgeon 1989). While carbon and nitrogen do not equally behave in a similar manner. Osaki et al. (1988) have demonstrated that nitrogen accumulation was almost ceased in rice, and the major part of nitrogen in reproductive organs is derived from those nitrogen absorbed and once incorporated into proteins in leaves. While as Tanaka and Osaki (1983) shown that major part of carbon in reproductive organ of rice is derived from the photosynthate which are acquired around the 
same time. The physiological change in leaf is considered to be regulated by hormonal regulation such as cytokinin, but there is no direct evidence that cytokinin regulated the $\mathrm{C} / \mathrm{N}$ partitioning in plant. Further research is progressed.

It is suggested that the existence of more sophisticated regulation of SPS and PEPC by metabolites concentration and/or phosphorylation/dephosphorylation of each enzyme, rather regulated by mRNA expression level. But at least to our knowledge the integrated information about the over-all regulation of SPS and PEPC has not been reported yet. Though our report did not demonstrate the amount of each protein, it is speculated about the existence of protein level regulation, because 1) the expression pattern of mRNA and enzyme activity is different (comparing Figs 2 and 3), 2) SPS limiting activity to SPS $V_{\max }$ activity was not stable (Fig 3).

\section{Acknowledgement}

We used the Radioisotope Laboratory of the Graduate School of Agriculture, Hokkaido University.

\section{References}

Andrews, M: The pantitioning of nitate assimilation between root and shoot of

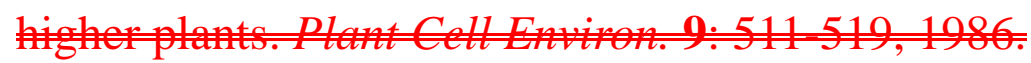

Bakrim, N., Brulfert, J., Vidal, J., Chollet, R.: Phosphoenolpyruvate carboxylase kinase is controlled by a similar signaling cascade in CAM and $\mathrm{C}_{4}$ plants. Biochem. Biophys. Res. Commum. - 286: 1158-1162, 2001. 
Buchanan-Wollaston, V., Ainsworth, C.: Leaf senescence in Brassica napus: cloning of senescence related genes by subtractive hybridization. - Plant mol. Biol. 33: 821-834, 1997.

Champigny, M.L., Foyer, C.: Nitrate activation of cytosolic protein kinases diverts photosynthetic carbon from sucrose to amino acid biosynthesis. Basis for new concept. - Plant Physiol. 100: 7-12, 1992.

Copeland, L., Turner, J.F.: The regulation of glycolysis and the pentose phosphate pathway. - In: Stumpf, P.K., Conn, E.E. (ed.): The Biochemistry of Plants. Pp. 107-128. Academic Press, New York 1987.

Duff, S.M.G., Chollet, R.: In vivo regulation of wheat-leaf phosphoenolpyruvate carboxylase by reversible phosphorylation. - Plant Physiol. 107: 775-782, 1995.

Fellows, R.J., Geiger, D.R.: Structural and physiological changes in sugar beet leaves during sink to source conversion. - Plant Physiol. 54: 877-885, 1974.

Foyer, C., Noctor, G., Leleandais, M., Lescure, J.C., Valadier, M.H., Horton, P.: Shot-term effects of nitrate, nitrite and ammonium assimilation on photosynthesis, carbon partitioning and protein phosphorylation in maize. Planta 192: 211-220, 1994.

Foyer, C.H., Valadier, M.H., Ferrario, S.: Co-regulation of nitrogen and carbon assimilation in leaves. - In: Smirnoff, N. (ed.): Environment and Plant Metabolism. Pp. 17-33. BIOS Scientific Publishers, Oxford 1995.

Galtier, C.H., Foyer, C., Huber, J.L., Boelker, T.A., Huber, S.C.: Effects of elevated sucrose-phosphate synthase activity on photosynthesis, assimilate 
protecting, and growth in tomato (Lycopersicon esculentum var. UC82B). Plant Physiol. 101: 535-543, 1993.

Galtier, C.H., Foyer, C.H., Murchie, E., Alred, R., Quick, P., Voelker, T.A., Thépenier, C., Lascève, G., Betsche, T.: Effects of light and atmospheric carbon dioxide enrichment on photosynthesis and carbon partitioning in the leaves of tomato (Lycopersicon esculentum L.) plants over-expressing sucrose phosphate synthase. - J. exp. Bot. 46: 1335-1344, 1995.

Geigemberger, P., Stitt, M.: Regulation of camben pantitioning between suerese and nitrogen assimilation in cotyledons of germinating Ricinus communis $\mathrm{E}$. seedlings. Planta 185:563-568, 1991.

Huber, S.C., Huber, J.L.: Role of sucrose synthase in sucrose metabolism in leaves. Plant Physiol. 99: 673-678, 1992.

Huber, S.C., Huber, J.L.: Role and regulation of sucrose-phosphate-synthase in higher plants. - Annu. Rev. Plant Physiol. Plant mol. Biol. 47: 431-444, 1996.

Huber, J.L., Redinbaugh, M.G., Huber, S.C., Campbell, W.H.: Regulation of maize leaf nitrate reductase activity involves both gene expression and protein phosphorylation. - Plant Physiol. 106: 1667-1674, 1994.

Huppe, H.C., Turpin, D.H.: Integration of carbon and nitrogen metabolism in plant and algal cells. - Annu. Rev. Plant Physiol. Plant mol. Biol. 45: 577-607, 1994.

Kamachi, K., Yamaya, T., Mae, T., Ojima, K.: A role for glutamine synthetase in the remobilization of leaf nitrogen during natural senescence in rice leaves. Plant Physiol. 96: 411-417, 1991. 
Kawakami, N., Watanabe, A.: Senescence-specific increase in cytosolic gutamine synthetase and its mRNA in radish cotyledons. - Plant Physiol. 88: 1430-1434, 1988.

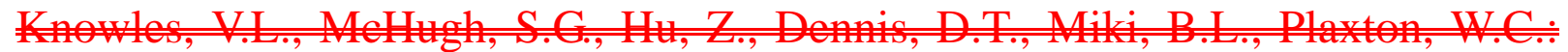

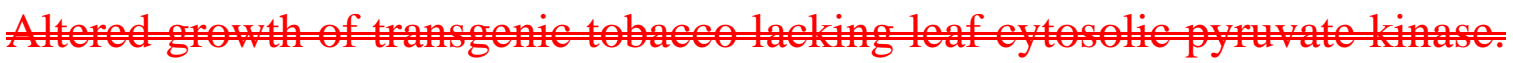
Plant Physiol. 116:45-51, 1998.

Koga, N., Ikeda, M.: Responses to nitrogen sources and regulatory properties of root phosphoenolpyruvate carboxylase. - Soil Sci. Plant Nutr. 43: 643-650, 1997.

Kozaki, A., Takeba, G.: Photorespiration protects $\mathrm{C}_{3}$ plants from photooxidation. Nature 384: 557-560, 1996.

Laporte, M.M., Galagan, J.A., Prasch, A.L., Vanderveer, P.J., Hanson, D.T., Shewmaker, C.K., Sharkey, T.D.: Promoter strength and tissue specificity effects on growth of tomato plants transformed with maize sucrose-phosphate synthase. Planta 212: 817-22, 2001.

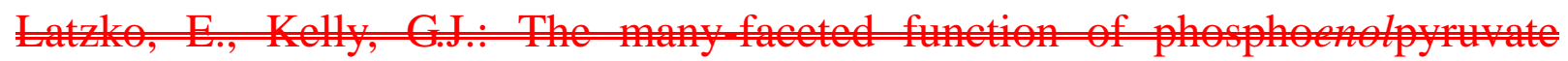
eambexylase in $G_{3}$ plants. Physiol. Veg. 21:805-815, 1983 .

E,, , Zhang, $X Q$, , Choll, R.:PEPG lina in

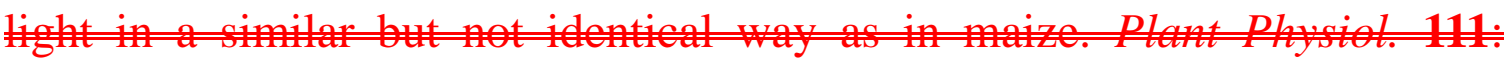
497-505, 1996.

MacKintosh, C.: Regulation of plant nitrate assimilation: from ecophysiology to brain proteins. - New Phytol. 139: 153-159, 1998. 
21:761774, 1983.

Melzer, E., $O^{\prime}$ teary, M.H.: Anaplerotic $\mathrm{G}_{z}$ fixation by phosphoenolpyruvate .

Micallef, B.J., Haskins, K.A., Vanderveer, P.J., Roh, K-S., Shewmaker, C.K., Sharkey, T.D.: Altered photosynthesis, flowering, and fruiting in transgenic tomato plants that have an increased capacity for sucrose synthesis. - Planta 196: 327-334, 1995.

Murchie, E.H., Sarrobert, C., Contard, P., Betsche, T., Foyer, C., Galtier, N.: Overexpression of sucrose-phosphate synthase in tomato plants grown with $\mathrm{CO}_{2}$ enrichment leads to decreased controls. - Plant Physiol. Biochem. 37: 251-260, 1999.

Nakamura, T., Osaki, M., Shinano, T., Tadano, T.: Difference in system of current photosynthesized carbon distribution to carbon and nitrogen compounds between rice and soybean. Soil Sci. Plant Nutr. 43: 777-788, 1997.

Osaki, M.: Ontogenic changes of N, P, and $K$ contents in individual leaves of field exops. Soil Sei. Plant Nutr. 41:429-438, 1995.

Osaki, M., Hada, K., Tanaka, A.: [Reconstruction of the leaf-proteins into grain-proteins during ripening in the rice plant.] Jap. J. Soil Sci. Plant Nutr. 59: 272-278, 1988. [In Jap. with English summary].

Osaki, M., Shinanø, T., Kaneda, T., Yamada, S., Nakammma, T.: Ontogenetie ehanges of photosynthetic and dark respiration rates in relation to nitrogen eontent in individual leaves of field erops. Photosynthetica 39: 205-213, 2001. 
Osaki, M., Shinano, T., Tadano, T.: Carbon-nitrogen interaction in field crop production. - Soil Sci. Plant Nutr. 38: 553-564, 1992.

Palmiter, R.D.: Magnesium precipitation of ribonucleoprotein complexes: expedient techniques for the isolation of undegraded polysomes and messenger ribonucleic acid. - Biochemistry 13: 3606-3615, 1974.

Plaxton, W.C.: The organization and regulation of plant glycolysis. - Annu. Rev. Plant Physiol. Plant mol. Biol. 47: 185-214, 1996.

Plaxton, W.C., Sangwan, R.S., Singh, N., Gauthier, D.A., Turpin, D.H.: Phosphoenolpyruvate metabolism of developing oil seeds. - In: MacKenzie, S.L., Taylor, D.C. (ed.): Seed Oils for the Future. Pp. 35-43. AOCS Press, Champaign, USA. 1993.

Plumley, F.G., Schmidt, G.W.: Nitrogen-dependent regulation of photosynthetic gene expression. - Proc. nat. Acad. Sci. USA 86: 2678-2682, 1989.

Quy, L.V., Champigny, M-L.: $\mathrm{NO}_{3}^{-}$enhances the kinase activity for phosphorylation of phosphoenolpyruvate carboxylase and sucrose phosphate synthase proteins in wheat leaves. - Plant Physiol. 99: 344-347, 1992.

Quy, L.V., Foyer, C., Champigny, M.L.: Effect of light and $\mathrm{NO}_{3}{ }^{-}$on wheat leaf phosphoenolpyruvate carboxylase activity. Evidence for covalent modulation of the $C_{3}$ enzyme. - Plant Physiol. 97: 1476-1482, 1991.

Rademacher, T., Hausler, R.E., Hirsch, H.J., Zhang, L., Lipka, V., Weier, D., Kreuzaler, F., Peterhansel, C.: An engineered phosphoenolpyruvate carboxylase redirects carbon and nitrogen flow in transgenic potato plants. Plant J. 32: 25-39, 2002. 
Redimbaugh, M.G., Gampbell, W.H.: Glutamine synthetase and ferredoxin-dependent glutamate synthase expression in the maize (Zea mays)

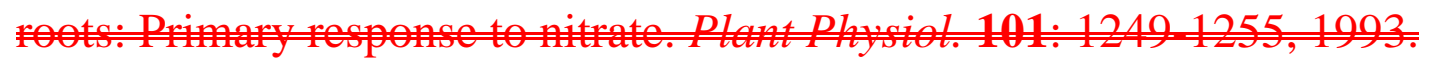

Sagi, M., Dovrat, A., Kipnis, T., Lips, H.: Nitrate reductase, phosphoenolpyruvate carboxylase, and glutamine synthetase in annual ryegrass as affected by salinity and nitrogen. - J. Plant Nutr. 21: 707-723, 1998.

Sakakibara, H., Kawabata, S., Hase, T., Sugiyama, T.: Differential effects of nitrate and light on the expression of glutamine synthetases and ferredoxin-dependent glutamate synthase in maize. - Plant Cell Physiol. 33: 1193-1198, 1992.

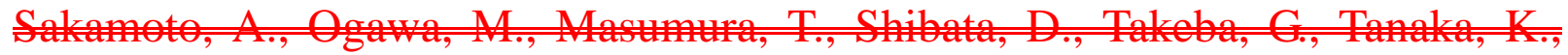

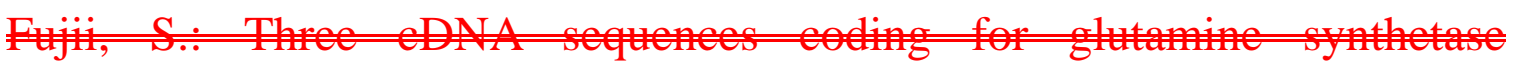

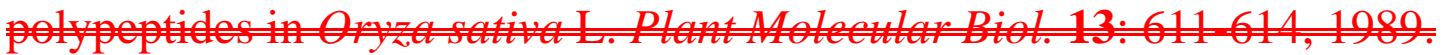

Scheible, W.R., González-Fontes, A., Laulere, M., Müller-Röbber, B., Gaboche, M., Stitt, M: Nitrate acts as a signal to indene organic acid metabolism and repress-starch metabolism in tobace. Plant Gell 9: 783-798, 1997.

Shinano, T., Osaki, M., Tadano, T.: Problems in the methods of estimation of growth and maintenance respiration. - Soil Sci. Plant Nutr. 42: 773-784, 1996. Shinano, T., Osaki, M., Tadano, T.: ${ }^{14} \mathrm{C}$-allocation of ${ }^{14} \mathrm{C}$-compounds introduced to a leaf to carbon and nitrogen components in rice and soybean during ripening.

- Soil Sci. Plant Nutr. 40: 199-210, 1994.

Signora, L., Galtier, N., Skt, L., Lucas, H., Foyer, C.: Overexpression of sucrose phosphate synthase in Arabidopsis thaliana results in increased folia 
sucrose/starch ratios and favours decreased foliar carbohydrate accumulation in plants after prolonged growth with $\mathrm{CO}_{2}$ enrichment. - J. exp. Bot. 49: 669-680, 1998.

Speins, J., B y, G.J.:A

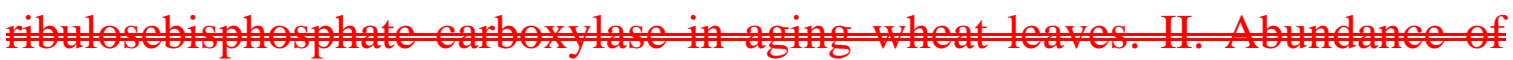
messenger RNA. Aust. J. Plant Physiol. 8: 591-602, 1981.

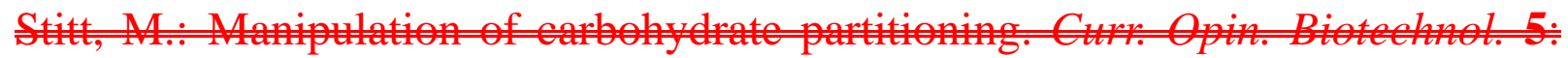
137-143, 1994.

Stitt, M.: Nitrate regulation of metabolism and growth. - Curr. Opin. Plant Biol. 2: 178-186, 1999.

Stitt, M., Gerhardt, R., Wilke, I., Heldt, H.W.: The contribution of fructose 2,6-bisphosphate to the regulation of sucrose synthesis during photosynthesis. - Physiol. Plant. 69: 377-386, 1987.

Stitt, M., Wilke, I., Feil, R., Heldt, H.W.: Coarse control of sucrose-phosphate synthase in leaves: Alterations of the kinetic properties in response to the rate of photosynthesis and the accumulation of sucrose. - Planta 174: 217-230, 1988.

Sugiharto, B., Sugiyama, T.: Effects of nitrate and ammonium on gene expression of phosphoenolpyruvate carboxylase and nitrogen metabolism in maize leaf tissue during recovery from nitrogen stress. - Plant Physiol. 98: 1403-1408, 1992.

Sugiharto, B., Suzuki, I., Burnell, J.N., Sugiyama, T.: Glutamine induces the N-dependent accumulation of mRNAs encoding phosphoenolpyruvate 
carboxylase and carbonic anhydrase in detached maize leaf tissue. - Plant Physiol. 100: 2066-2070, 1992.

Suzuki, I., Crétin, C., Omata, T., Sugiyama, T.: Transcriptional and posttranscriptional regulation of nitrogen-responding expression of phosphoenolpyruvate carboxylase gene in maize. - Plant Physiol. 105: 1223-1229, 1994.

Suzuki, Y., Makino, A., Mae, T.: Changes in the tumover of Rubiseo and levels of mRNAs of rbet and rbes in rice leaves from emengenesenestant Gell 24:1353-1360,2001.

Tanaka, A., Osaki, M.: Growth and behavior of photosynthesized ${ }^{14} \mathrm{C}$ in various crops in relation to productivity. - Soil Sci. Plant Nutr. 29: 147-158, 1983.

Taybi, T., Patil, S., Chollet, R., Cushman, J.C.: A minimal serine/threonine protein kinase circadianly regulates phosphoenolpyruvate carboxylase in Crassulacean acid metabolism-induced leaves of the common ice plants. Plant Physiol. 123: 1471-1481, 2000.

Turgeon, R.: The sink-source transition in leaves. - Annu. Rev. Plant Physiol. Plant mol. Biol. 40: 119-138, 1989.

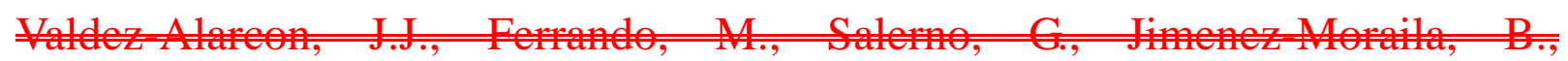

Hemera-Estrella, L.: Characterization of a rice strerose-phosphate sto $170: 2172222,1996$.

Vanlerberghe, G.C., Schuller, K.A., Smith, R.G., Feil, R., Plaxton, W.C., Turpin, D.H.: Relationship between $\mathrm{NH}_{4}{ }^{+}$assimilation rate and in vivo phosphoenolpyruvate carboxylase activity. Regulation of anaplerotic carbon 
flow in the green alga Selenastrum minutum. - Plant Physiol. 94: 284-290, 1990.

Vidal, J., Chollet, R.: Regulatory phosphorylation of $\mathrm{C}_{4}$ PEP carboxylase. - Trends Plant Sci. 2: 230-237, 1997.

Wallenda, T., Schaefeer, C., Einig, W., Wingler, A., Hampp, U., Seith, B., George, E., Marshner, H.: Effects of varied soil nitrogen supply on Norway spruce (Picea abies (L.) Karst.). - Plant Soil 186: 361-369, 1996.

Worrel, A.C., Bruneau, J-M., Summerfelt, K., Boersig, M., Voelker, T.A.: Expression of a maize sucrose phosphate synthase in tomato alters leaf carbohydrate partitioning. - Plant Cell 3: 1121-1130, 1991. 


\section{Legends}

Fig. 1 Development of the content of $\mathrm{N}$ and total RNA in leaves of rice plants under standard $(0.5 \mathrm{~N})$ and excess $(3.0 \mathrm{~N}) \mathrm{N}$ conditions. Error bars indicate s.e. I: vegetative growth stage, II: panicle formation stage, III: milk-ripe stage, IV: maturing stage.

Fig. 2 Relative mRNA levels of SPS, PEPC, PK, Rubisco, GS1, and GSS2 in different leaves at different developmental stages. mRNA levels are expressed as values relative to the strongest expression for each enzyme in each $\mathrm{N}$ treatment. Thin line: standard $(0.5 \mathrm{~N}) \mathrm{N}$ treatment; bold line: excess $(3.0 \mathrm{~N}) \mathrm{N}$ treatment.

I: vegetative growth stage, II: panicle formation stage, III: milk-ripe stage, IV: maturing stage.

Fig. 3 Development of the activity of PEPC, SPS $V_{\max }$, and SPS limiting activity in the leaves of rice plants under standard $(0.5 \mathrm{~N})$ and excess $(3.0 \mathrm{~N}) \mathrm{N}$ treatments. Error bars indicate standard error.

$$
O: 5^{\text {th }} \text { leaf } \triangleleft: 7^{\text {th }} \text { leaf; }: 9^{\text {th }} \text { leaf; } \boldsymbol{\Delta}: \text { flag leaf. }
$$

I: vegetative growth stage, II: panicle formation stage, III: milk-ripe stage, IV: maturing stage.

Fig. 4 Correlation of the activities of PEPC and SPS. A: Relationship between SPS $\mathrm{V}_{\max }$ and PEPC activity. B: Relationship between SPS limiting activity and PEPC activity. The thin lines represent leaves developed during the vegetative growth 
stage $\left(5^{\text {th }}\right.$ and $7^{\text {th }}$ leaf); the bold lines show results from leaves developed during the reproductive growth stage ( $9^{\text {th }}$ and flag leaf).

$\bigcirc: 5^{\text {th }}$ leaf; $\triangle: 7^{\text {th }}$ leaf; $\quad$ : $9^{\text {th }}$ leaf; $\boldsymbol{\Delta}$ : flag leaf of standard $(0.5 \mathrm{~N}) \mathrm{N}$ treatment and

$\square: 5^{\text {th }}$ leaf; $\nabla: 7^{\text {th }}$ leaf; $\quad \mathbf{\square}: 9^{\text {th }}$ leaf; $\boldsymbol{\nabla}$ : flag leaf of excess $(3.0 \mathrm{~N}) \mathrm{N}$ treatment. PEPC activity $=1.359 \times$ SPS $V_{\max }+8.323\left(r^{2}=0.369 * a, n=44\right)\left(5^{\text {th }}\right.$ and $7^{\text {th }}$ leaves, narrow line)

PEPC activity $=2.423 \times$ SPS $V_{\text {max }}+1.230\left(r^{2}=0.687^{*}, n=40\right)\left(9^{\text {th }}\right.$ and flag leaves, thick line)

PEPC activity $=4.529 \times$ SPS limiting activity $+9.027\left(r^{2}=0.154, n=44\right)\left(5^{\text {th }}\right.$ and $7^{\text {th }}$ leaves, narrow line)

PEPC activity $=10.44 x$ SPS limiting activity $+0.3492\left(r^{2}=0.669 *, n=40\right)\left(9^{\text {th }}\right.$ and flag leaves, thick line)

${ }^{\mathrm{a}}$ Asteroids denote significance of $\mathrm{t}$ ratio. ${ }^{*}, \mathrm{P}<0.001$.

Fig. 5 Relationship between nitrogen content and SPS $V_{\max }$, SPS limiting activity, and PEPC activity, respectively.

O: $5^{\text {th }}$ leaf; $\Delta 7^{\text {th }}$ leaf; $\quad 9^{\text {th }}$ leaf; $\quad$ : Alag leaf of standard $(0.5 \mathrm{~N}) \mathrm{N}$ treatment and $\square: 5^{\text {th }}$ leaf; $\nabla: 7^{\text {th }}$ leaf; $\boldsymbol{\square}: 9^{\text {th }}$ leaf; $\nabla$ : flag leaf of excess $(3.0 \mathrm{~N}) \mathrm{N}$ treatment.

A; Relationship between nitrogen content and SPS $\mathrm{V}_{\max }$.

B; Relationship between nitrogen content and SPS limiting activity.

C; Relationship between nitrogen content and PEPC activity.

PEPC activity $=0.200 \times \mathrm{N}$ content $+5.98\left(\mathrm{r}^{2}=0.306^{*}, \mathrm{n}=44\right)\left(5^{\text {th }}\right.$ and $7^{\text {th }}$ leaves, 
narrow line)

PEPC activity $=0.309 \times \mathrm{N}$ content $-0.467\left(\mathrm{r}^{2}=0.713^{*}, \mathrm{n}=40\right)\left(9^{\text {th }}\right.$ and flag leaves, thick line)

SPS Vmax $=0.128 \times N$ content $-1.06\left(r^{2}=0.630 *, n=44\right)\left(5^{\text {th }}\right.$ and $7^{\text {th }}$ leaves, narrow line)

SPS Vmax $=0.110 \times \mathrm{N}$ content $-0.178\left(\mathrm{r}^{2}=0.766^{*}, \mathrm{n}=40\right)\left(9^{\text {th }}\right.$ and flag leaves, thick line)

SPS limiting activity $=0.00515 \times \mathrm{N}$ content $+0.718\left(\mathrm{r}^{2}=0.027, \mathrm{n}=44\right)\left(5^{\mathrm{th}}\right.$ and $7^{\mathrm{th}}$ leaves, narrow line)

SPS limiting activity $=0.0229 \times \mathrm{N}$ content $+0.117 \mathrm{r}^{2}=\left(0.636^{*}, \mathrm{n}=40\right)\left(9^{\text {th }}\right.$ and flag leaves, thick line)

${ }^{\mathrm{a}}$ Asteroids denote significance of t ratio. *, $\mathrm{P}<0.001$.

Fig. $6{ }^{14} \mathrm{C}$ distribution to various classes of compounds at the end of a 5 min period of exposure to ${ }^{14} \mathrm{C}$ assimilation in individual leaves at various developmental stages. Values shown on top of the bars indicate total nitrogen content. Error bars indicate standard error.

Fig. 7 Relationship between $\mathrm{N}$ content and the proportion of ${ }^{14} \mathrm{C}$ distribution to the $\mathrm{N}$-pool (free amino acids and proteins) in leaves at the end of 5 min exposure to ${ }^{14} \mathrm{CO}_{2}$. The relationship between the parameters is significantly different in the $6^{\text {th }}$ leaf from that in other leaves.

$\bigcirc: 6^{\text {th }}$ leaf; $\square: 8^{\text {th }}$ leaf; $\triangle: 9^{\text {th }}$ leaf; $\diamond: 10^{\text {th }}$ leaf; $\nabla: 11^{\text {th }}$ leaf. 


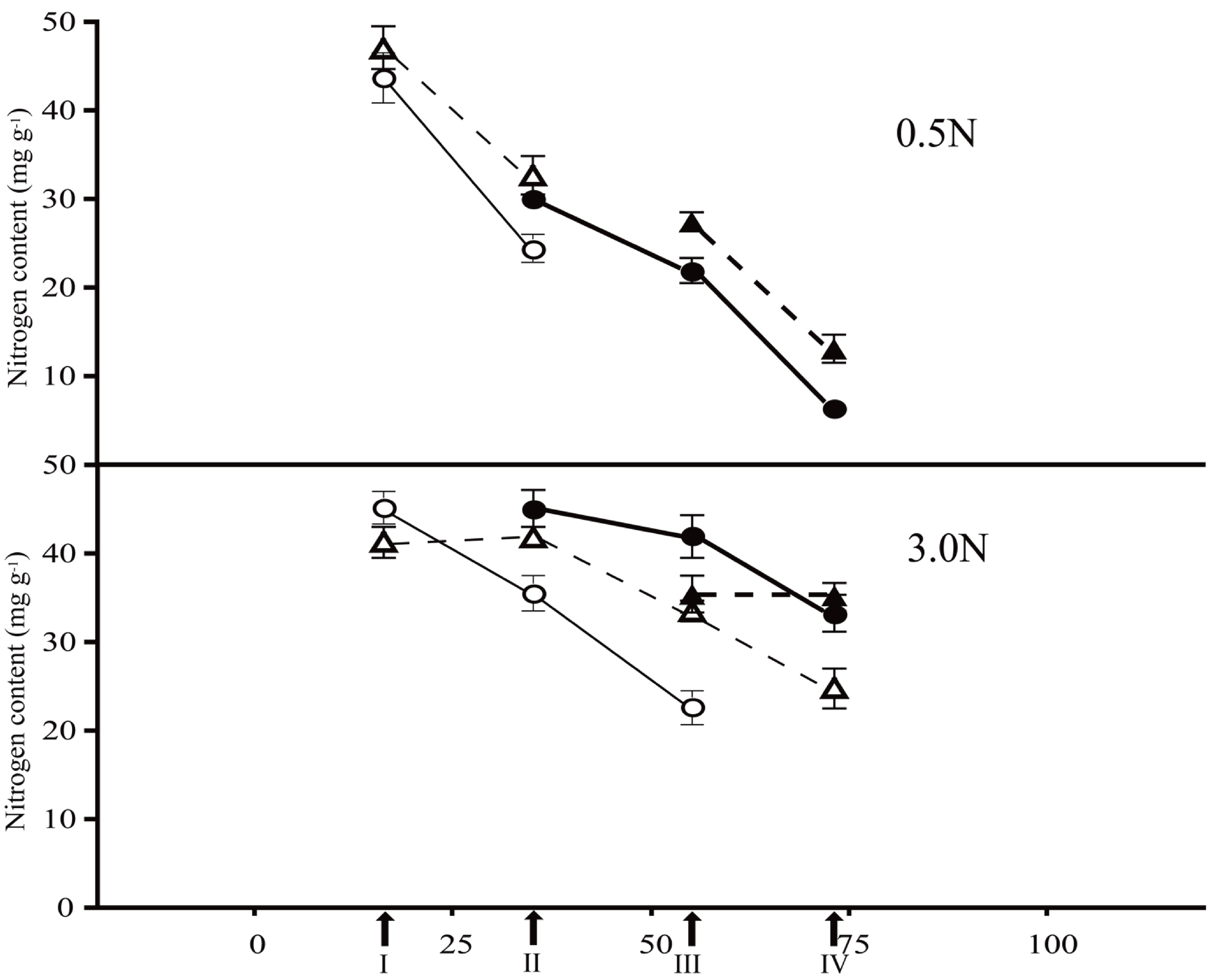

Days after transplanting 

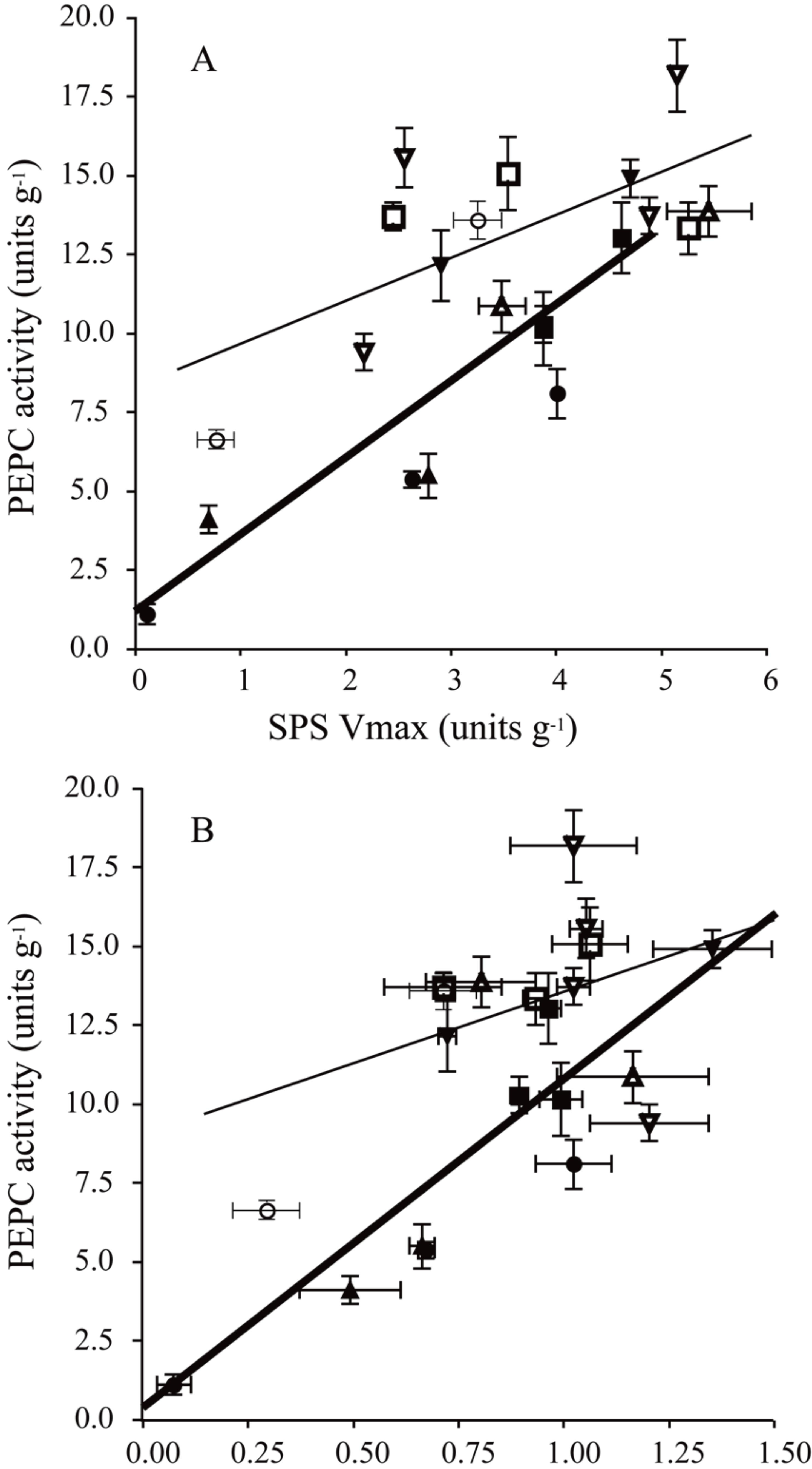


$$
\text { 篓 }
$$


Nitrogen content $\left(\mathrm{mg} \mathrm{g}^{-1}\right)$

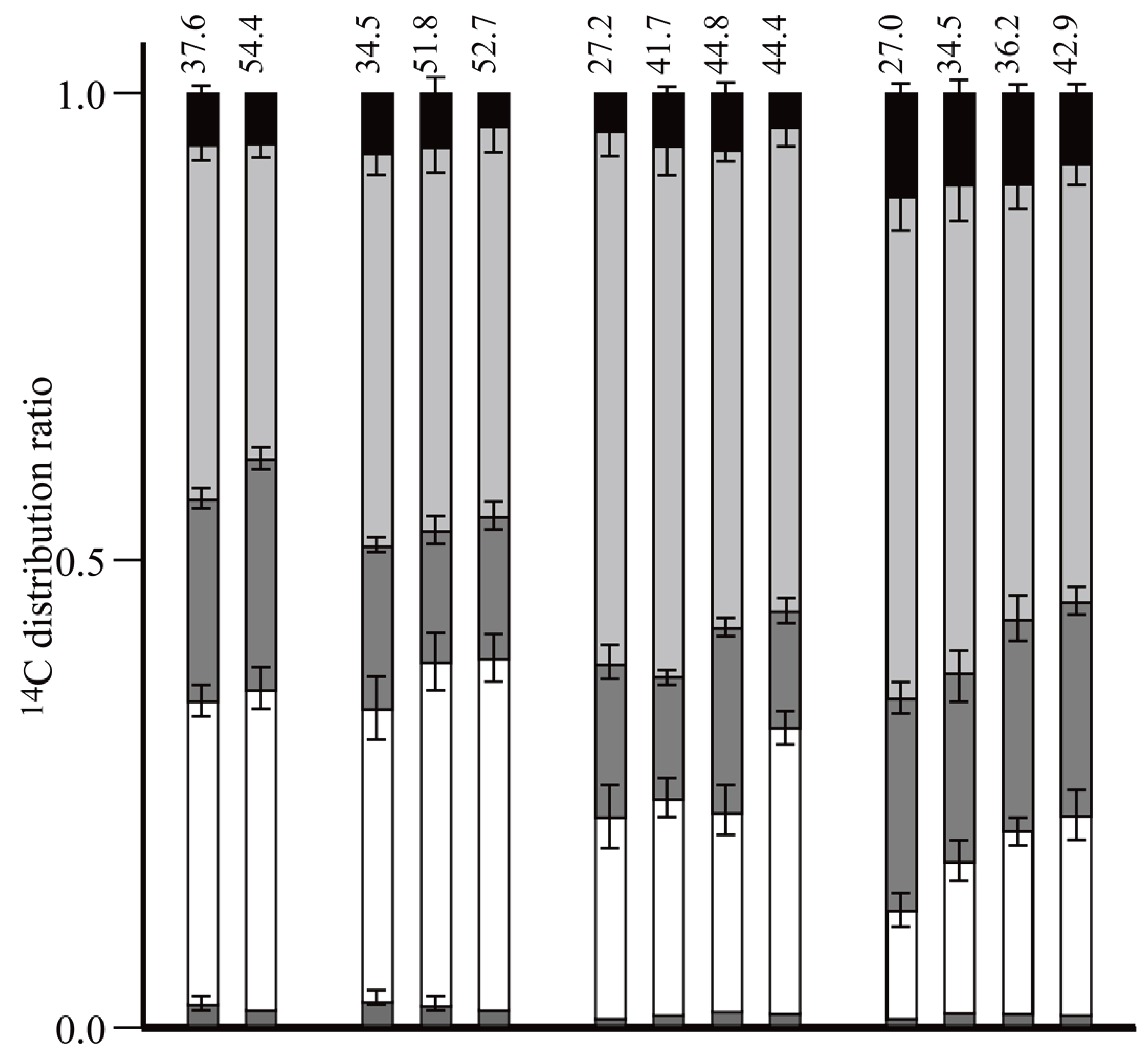

Leaf position

Days after transplanting

$\begin{array}{lllll}6 \quad 8 & 6 \quad 8 \quad 9 \\ 28 & & 6 & 6\end{array}$

\begin{tabular}{llll}
$8 \quad 9$ & 10 & 11 \\
\hline
\end{tabular}

Dolysaccharides

$\square$ Sugars

$\square$ Organic acids

$\square$ Free amino acids

$\square$ Protein 


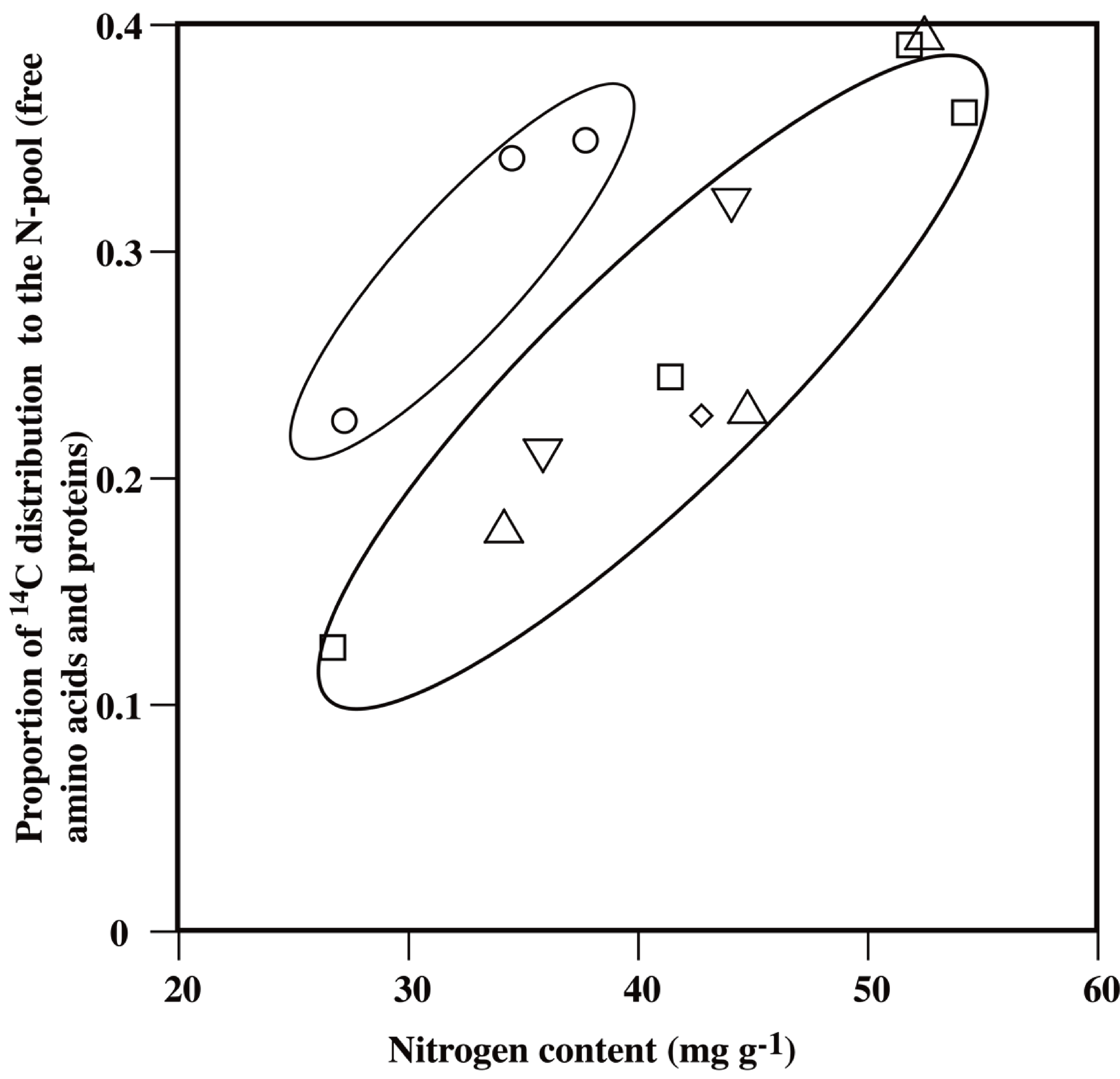

